\title{
LETTER
}

\section{Origin of graphite in glimmerite and spinellite in Achankovil Shear Zone, southern India}

\author{
V.J. RAJESH*, Shoji Arai ${ }^{*}$ and M. Satish-Kumar ${ }^{* *}$ \\ *Department of Earth Sciences, Kanazawa University, \\ Kakuma-machi, Kanazawa 920-1192, Japan \\ ** Institute of Geosciences, Shizuoka University, Suruga-ku, \\ Ohya 836, Shizuoka 422-8529, Japan
}

\begin{abstract}
We report occurrence and origin of graphite in glimmerite and spinellite from an unusual ultramafic complex in Achankovil Shear Zone (ACSZ) in southern India. Raman analyses of primary graphite flakes in close association with spinel and phlogopite confirm the highly crystalline nature. The carbon isotope composition ranges from $-7 \%$ to $-9.8 \%$ typical of mantle-derived graphite. A genetic model is proposed in which carbon was derived from a reduced juvenile mantle source linked to the genesis of volatile rich ultramafic rocks in ACSZ.
\end{abstract}

Keywords: Graphite, Glimmerite, Spinellite, Achankovil shear zone, Southern India

\section{INTRODUCTION}

Elemental carbon (C) occurs as graphite and diamond in nature. These two forms of $\mathrm{C}$ are also present in many mantle-derived rocks where they exert significant control on the redox conditions in magma genesis. Graphite is abundant in wide variety of mantle rocks when compared to diamond (Pineau et al., 1987; Dienes, 2002). In general, there are two important mechanisms of formation of graphite: i) graphitization of biogenic materials during metamorphism and ii) precipitation of graphite from carbon-bearing fluids. The former is relatively simple and progress with structural and crystallographic maturation with increasing grade of metamorphism. However, the later involves a complex mechanism involving different fluid species (e.g., $\mathrm{CO}_{2}, \mathrm{CH}_{4}$, $\mathrm{CO}$ etc.) of various sources (e.g., mantle carbon, $\mathrm{CO}_{2}$ from decarbonation reactions, $\mathrm{CO}_{2}$ outgassed from melts etc.; Weis et al., 1981; Mattey, 1987; Satish-Kumar et al., 2002; Binu-lal et al., 2003; Lamb and Valley, 1985; Pineau et al., 1987; Luque et al., 1992, 1998, 2009; Farquhar et al., 1999). Stable isotopic composition of $\mathrm{C}$ is a powerful geochemical tool widely employed for interpretation of the origin/source of carbon, based on fractionation of carbon isotopes during various surface and subsurface processes. In a recent study, Di-

doi:10.2465/jmps.090622d

V.J. Rajesh, rajeshvj@earth.s.kanazawa-u.ac.jp Corresponding author S. Arai, ultrasa@kenroku.kanazawa-u.ac.jp

M. Satish-Kumar, smsatis@ipc.shizuoka.ac.jp enes et al. (2009) suggested that the carbon isotopic composition of mantle is heterogeneous and can not be explicitly explained using recycling of crustal carbon. It is therefore essential to understand the carbon isotopic signature of mantle derived rocks in more detail. Rajesh et al. (2004, 2006) and Rajesh and Arai (2006) reported the occurrence of graphite-bearing ultramafic rocks from the Achankovil Shear Zone, southern India, where they invoked an unusual $\mathrm{C}-\mathrm{O}-\mathrm{H}-\mathrm{S}$ volatile-rich magmatic environment.

In this contribution we characterize the occurrence of graphite in spinellite and glimmerite on the basis of Laser Raman spectra and stable C-isotope compositions. Our study has important implications for genesis of graphite, and the behavior of carbon species in a magmatic system in a Neoproterozoic shear zone in southern India.

\section{GEOLOGICAL SETTING AND PETROGRAPHY}

The study area lies $\sim 15 \mathrm{~km}$ northeast of Punalur within the Achankovil Shear Zone (ACSZ) in the Southern Granulite Terrain (SGT), India (Fig. 1). The SGT is composed of a variety of granulite blocks that underwent extreme crustal metamorphism during late NeoproterozoicCambrian time and is dissected by major transcrustal shear zones (Drury and Holt, 1980; Drury et al., 1984 and so on). The ACSZ, which appears as a prominent lineament in aeromagnetic and satellite images, trends NW-SE with a width of $\sim 15 \mathrm{~km}$ and a lateral extension of $\sim 120$ 


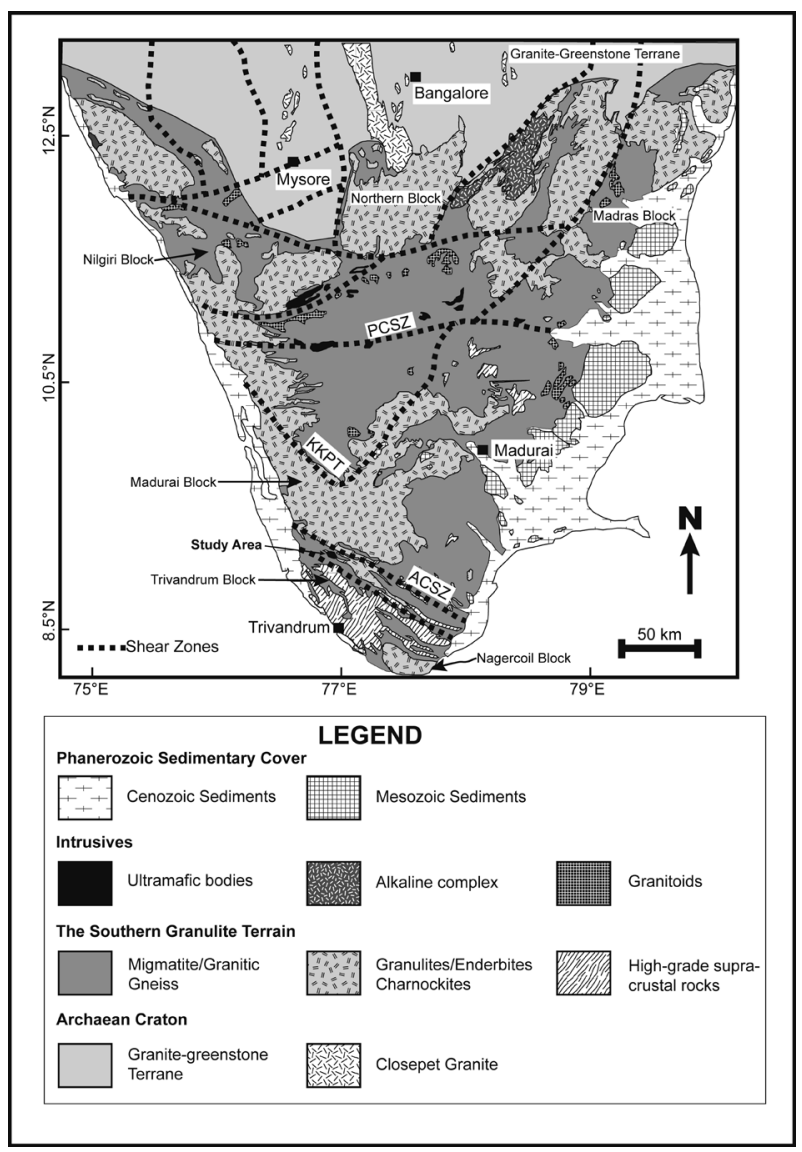

Figure 1. Generalized tectonic and geological framework of southern granulite terrain in South India (modified after Geological Survey of India, 1995; Ghosh et al., 2004; Rajesh et al., 2004, 2006).

km (Drury et al., 1984; Guru Rajesh and Chetty, 2006). ACSZ has figured prominently as a deep-rooted shear zone of intercontinental scale in many Gondwana reconstruction models (e.g., Windley et al., 1994 and references therein). It is bounded to the north by the massif charnockites and intercalated high to ultrahigh temperature grade metasediments of the Madurai block (MB), and to the south by high temperature granulite facies supracrustals of the Trivandrum block (TB) (Drury et al., 1984; Bartlett et al., 1998; Shimpo et al., 2006). Rocks in ACSZ are dominated by intensely deformed garnetiferous biotite gneiss, quartzofeldspathic gneiss, cordierite-orthopyroxene gneiss, and charnockite (e.g., Santosh, 1987; Nandakumar and Harley, 2000; Cenki et al., 2004; Ishii et al., 2006). Neoproterozoic-Early Ordovician magmatisms of varying geochemical affinities from ultramafic to felsic compositions are also reported from ACSZ (e.g., Rajesh et al., 1996, Rajesh 2004; Santosh et al., 2005). The samples of present study belong to the ultramafic intrusive complex in ACSZ previously described by Rajesh et al. (2004, 2006) and Rajesh and Arai (2006). Comprehensive
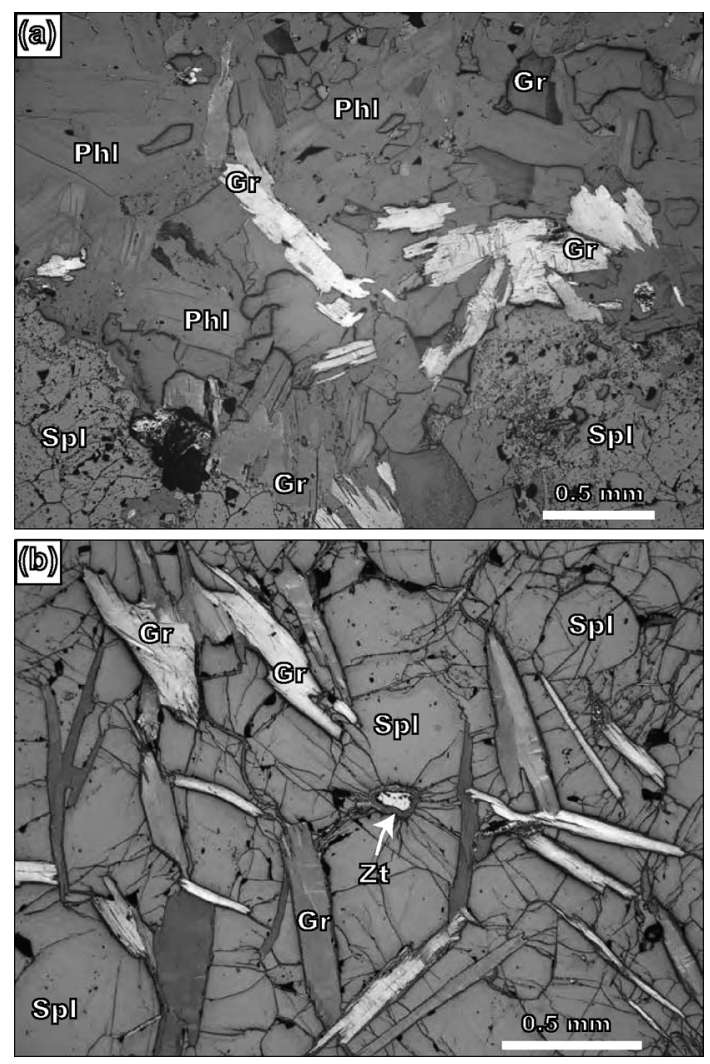

Figure 2. Transmitted-light photomicrographs showing the occurrence of graphite in glimmerite (a) and spinellite (b). Gr, graphite; Spl, spinel; Phl, phlogopite; Zt, zirconolite.

depiction of the lithological heterogeneities of this ultramafic complex is given in Rajesh et al. $(2004,2006)$.

The samples selected for the present study comprise graphite-bearing glimmerite and spinellite from the central and the western part of the ultramafic complex. Glimmerite is a coarse-grained rock and basically consists of phlogopite with or without minor rutile and ilmenite; the variants include graphite-bearing, and graphite- and spinel-bearing glimmerites. Graphite crystals ( $\sim 5 \mathrm{vol} \%$; size of which ranges from 80 to $300 \mu \mathrm{m}$ by width and 180 to $580 \mu \mathrm{m}$ by length) either occurs as randomly oriented disseminated flakes in close association with phlogopite, or partly or entirely enclosed by the spinel aggregates (Fig. 2a) not in contact with phlogopite. At places graphite is found in contact with sulfides such as pyrite and pyrrhotite. Spinellite is also a coarse-grained rock with abundant interconnected grains of spinel, the interstices of which are occupied by flaky graphite (Fig. 2b). Graphite flakes (up to $50-300 \mu \mathrm{m}$ wide and $150-750 \mu \mathrm{m}$ long) constitute $\sim 45 \mathrm{vol} \%$ of this rock. Rare zirconium-rich accessory minerals such as baddeleyite and zirconolite are found as interstitial and inclusion minerals in graphite-spinel bearing glimmerite and spinellite, respectively (Rajesh et al., 2006 and Rajesh and Arai, 2006). Spinel in glimmerite 

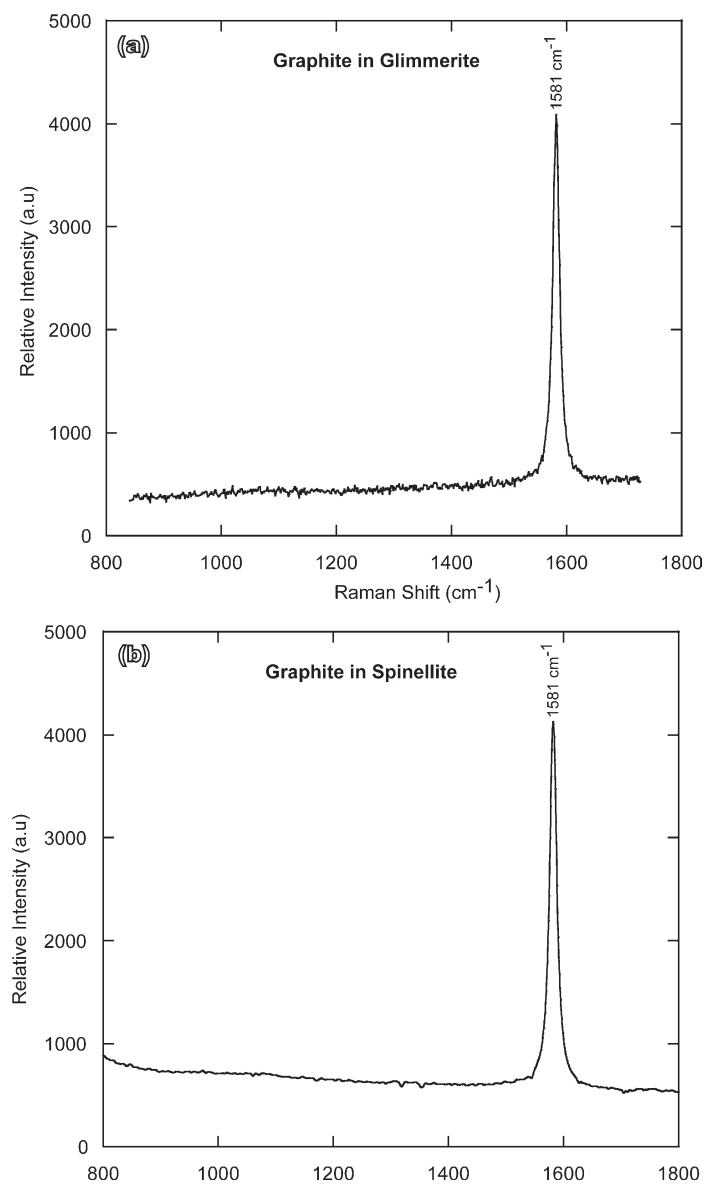

Figure 3. Laser Raman first-order spectrum characteristic of highly crystalline graphite in glimmerite (a) and spinellite (b).

and spinellite contain abundant fluid, melt and mineral inclusions (Rajesh, 2004).

\section{ANALYTICAL METHODS AND RESULTS}

Laser Raman spectroscopic analysis was utilized to characterize the matrix graphite using a JASCO-NRS 2000C Laser Raman Spectrometer at the Tokyo Institute of Technology, Japan with an $\mathrm{Ar}^{+}$laser $514.5 \mu \mathrm{m}$ excitation wavelength and a spot size of $1.0 \mu \mathrm{m}$. The analyses were carried out on graphite flakes and data were obtained at room temperature.

Stable C-isotope analyses of graphite were carried out at the Institute of Geosciences, Shizouka University, Japan. Analytical procedure is described in detail in Binulal et al. (2003) and Satish-Kumar (2005). Carbon isotopic compositions were measured using a Finnigan MAT250 Mass-spectrometer. The isotopic compositions are represented by the conventional $\delta$ notation with regard to PDB (for carbon) in \%o (per mil). Independent graphite standard prepared and measured using the same protocol gave $\delta^{13} \mathrm{C}$ reproducibility of $\pm 0.1 \%$ (Satish-Kumar, 2005).
Table 1. Stable C-isotope analysis of graphite in glimmerite and spinellite

\begin{tabular}{|c|c|c|c|c|}
\hline Sample No. & Nature of graphite & $\begin{array}{c}\delta^{13} \mathrm{C}_{\mathrm{PDB}} \\
(\% 0)\end{array}$ & Mean & $\sigma$ \\
\hline \multicolumn{5}{|c|}{ Graphite Glimmerite } \\
\hline PL1-1 & \multirow{6}{*}{$\begin{array}{l}\text { Graphite found } \\
\text { associated with } \\
\text { phlogopite }\end{array}$} & -8.3 & \multirow{6}{*}{-8.1} & \\
\hline PL1-2 & & -8.9 & & 0.5 \\
\hline PL1-3 & & -7.6 & & \\
\hline PL1-4 & & -8.2 & & \\
\hline PL1-5 & & -7.7 & & \\
\hline PL1-6 & & -7.6 & & \\
\hline \multicolumn{5}{|c|}{ Graphite-Spinel Glimmerite } \\
\hline P2a-1-1 & & -8.3 & \multirow{10}{*}{-8.5} & \\
\hline P2a-1-2 & Associated with & -9.8 & & \\
\hline P5a-1-1 & phlogopite and not in & -9.6 & & \\
\hline P5a-1-1a & contact with spinel & -8.8 & & \\
\hline $\begin{array}{l}\text { P5a-1-2 } \\
\text { P5a-1-2a }\end{array}$ & contact with spmer & $\begin{array}{l}-8.2 \\
-7.6\end{array}$ & & 0.8 \\
\hline P2a-2-1 & As inclusions with in & -8.2 & & \\
\hline P2a-2-2 & spinel aggregates & -7.5 & & \\
\hline P2a-3-1 & \multirow{3}{*}{$\begin{array}{l}\text { Closely associated or } \\
\text { in contact with spinel }\end{array}$} & -9.7 & & \\
\hline$P 2 a-3-2$ & & -7.7 & & \\
\hline P5a-2-2 & & -8.3 & & \\
\hline \multicolumn{5}{|c|}{ Phlogopite-Graphite Spinellite } \\
\hline 139SG3-1-1 & & -8.9 & \multirow{11}{*}{-8.0} & \\
\hline 139SG3-1-2 & & -7.9 & & \\
\hline 139SG3-1-3 & Closely associated or & -8.3 & & \\
\hline $\begin{array}{l}\text { 139SG3-1-3a } \\
139 S G 3 a-1-1\end{array}$ & in contact with spinel & $\begin{array}{l}-8.2 \\
-7.9\end{array}$ & & \\
\hline $\begin{array}{l}\text { 139SG3a-1-1a } \\
\text { 139SG3a-1-2 }\end{array}$ & & $\begin{array}{l}-7.1 \\
-8.2\end{array}$ & & 0.4 \\
\hline 139SG3-2-1 & & -7.9 & & \\
\hline 139SG3-2-1a & Flakes that are & -7.8 & & \\
\hline 139SG3-2-1b & rimmed by & -7.7 & & \\
\hline 139SG3-2-2 & & -7.7 & & \\
\hline 139SG3a-2-1 & phlog & -8.3 & & \\
\hline 139SG3a-2-2 & & -7.7 & & \\
\hline
\end{tabular}

PL1, P2a, P5a, 139SG3 and 139SG3a denote sample numbers. PL1-1, PL1-2 etc. are different fraction of graphite grains from the same sample PL1.

The same naming system is adopted for other samples.

Characteristic Raman spectra (first order spectra) of representative graphite from glimmerite and spinellite are shown in Figure 3. The analyzed graphite grains have a well defined first order peak around $1581 \mathrm{~cm}^{-1}$ and do not show any disordered peaks, which suggests a highly crystalline nature, comparable to high-T metamorphic graphite, vein graphite and also graphite from mantle xenoliths (Pasteris and Wopeka, 1991, Beyssac et al., 2002). The carbon isotopic composition of most of the graphite from glimmerite and spinellite has $\delta^{13} \mathrm{C}$ values in the range of -7.1 to $-9.8 \%$ (Table 1, Fig. 4).

\section{DISCUSSION}

$\mathrm{C}$ isotopic composition is an essential geochemical pa- 


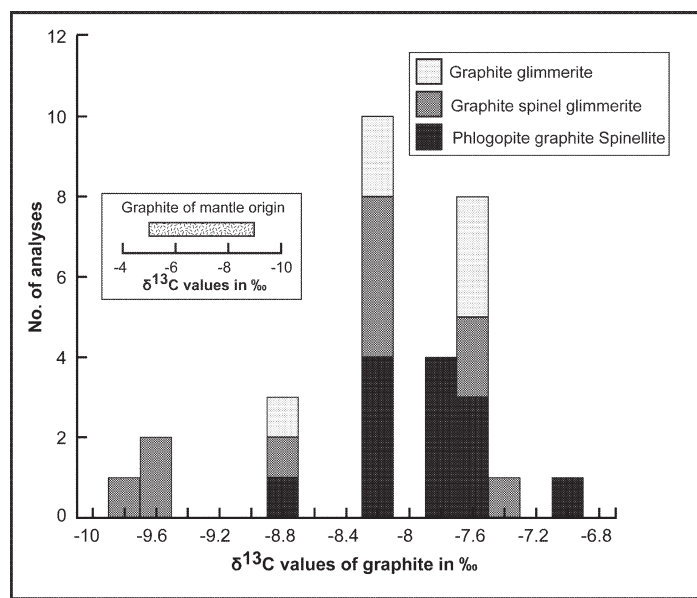

Figure 4. Histogram showing the distribution of carbon isotope compositions in graphite from glimmerite and spinellite. Inset shows the range of isotopic compositions for mantle derived graphite from different lithologies.

rameter to distinguish graphite formed from various sources. Carbon isotopic composition of mantle derived rocks, such as xenoliths, kimberlites and carbonatites has typical $\delta^{13} \mathrm{C}$ values that lie in between $-2 \%$ to $-9 \%$ (Dienes, 1989, 2002; Mattey, 1987; Hoefs, 1980; Javoy et al., 1986). This range of isotopic compositions is also observed for volcanic gases from continental volcanoes. The $\delta^{13} \mathrm{C}$ values measured in mid-ocean ridge basalts (MORB) glass are also in the range of -9 to $-3.4 \%$ for the $\mathrm{CO}_{2}$ gas in vesicles. However, lighter carbon isotopic composition of up to $-26 \%$ have been recently reported from the mantle diamonds and graphite (e.g., Dienes et al., 2009). Crespo et al (2006) also reported graphite with light C-isotope signatures from unusual graphite-sulfide deposits in mantle-derived ultramafic rocks from the Serranía de Ronda (Spain) and Beni Bousera (Morocco). The role of carbon recycling into mantle has generally been invoked as possible cause for lighter carbon in the mantle, although this is a subject of debate (see Dienes et al., 2009).

Graphite is a ubiquitous accessory phase in various high-grade metamorphic rocks and pegmatites in ACSZ and adjacent terrane of Trivandrum Block (e.g., Radhika and Santosh, 1996; Satish-Kumar et al., 2002). $\delta^{13} \mathrm{C}$ values of graphite from spinellite and glimmerite point to its derivation from a deep-seated (mantle) source. Therefore, the origin of graphite can be attributed to low $f_{\mathrm{O}_{2}}$ in the source. The isotopic values deny involvement of carbon of biogenic origin, when compared to the graphite present in the surrounding garnetiferous biotite gneiss, which shows much lighter values (>-20\%; Rajesh, 2004).

The presence of graphite and phlogopite of primary origin, primary $\mathrm{CO}_{2}$ fluid inclusions, magnesite and graphite solid inclusions in spinel suggest that the source melt is saturated with $\mathrm{CO}_{2}$ and $\mathrm{H}_{2} \mathrm{O}$. Occurrence of graphite as an interstitial mineral and inclusion in spinel together with $\delta^{13} \mathrm{C}$ values clearly suggests its primary nature, i.e., formation from a mantle-derived fluid/melt. The heavy $\delta^{13} \mathrm{C}$ values indicative of mantle values further suggest that the source area of this melt was relatively enriched in ${ }^{13} \mathrm{C}$. The limited range of isotopic variations among different samples in the ultramafic complex combined with enriched nature of ${ }^{13} \mathrm{C}$ can without a doubt exclude the involvement of recycled crustal carbon in the source melt.

The spinellite and glimmerite lack critical mineral equilibrium assemblage to estimate the $P-T$ conditions of crystallization. However, the homogenization temperatures of melt inclusions present in spinel in both spinellite and glimmerite are as high as $1050^{\circ} \mathrm{C}$ (Rajesh, 2004), indicating a minimum estimate of temperature of crystallization. The equilibrium isotopic fractionation between $\mathrm{CO}_{2}$ and graphite at $1000{ }^{\circ} \mathrm{C}$ is estimated in the range from $3 \%$ to $5 \%$ by experimental studies (Bottinga, 1969; Chacko et al., 1991; Polyakov and Kharlashina, 1995). Considering the isotopic fractionation between $\mathrm{CO}_{2}$ and graphite at the temperature of crystallization, the $\delta^{13} \mathrm{C}$ value of $\mathrm{CO}_{2}$ in the source melt is in the range of -5 to $-6 \%$, which is typical of mantle carbon. Minor shift observed in the $\delta^{13} \mathrm{C}$ values of graphite in individual lithological units (Fig. 4) is considered to be an outcome of fractionation during evolution from a $\mathrm{CO}_{2}$-rich melt/fluid. Rajesh et al. (2006) and Rajesh and Arai (2006) invoked the role of carbonatite-type melts in the genesis of spinellite in ACSZ. The presence of LREE-and Sr-enriched apatite, baddeleyite, zirconolite, perovskite and phlogopite together with mantle-like carbon isotope signatures and LREE-rich nature of carbonates (calcite) are definitely supportive of carbonatite-type of melts (Rajesh et al., 2006; Rajesh and Arai, 2006). Graphite was recently reported from dolomite carbonatite at Pogranichnoe, Russia, which also has mantle carbon isotope signatures (Doroshkevich et al., 2007). We believe that $C$ responsible for the formation of graphite in these rocks was in the form of $\mathrm{CO}_{2}$ in the source melts and the crystallization of graphite occurred by $\mathrm{C}$ saturation under reduced environment and continued until it reach higher oxidation state. We consider that sulfides (pyrrhotite and pyrite) present in the rock acted as a reducing agent that resulted in the precipitation of graphite from a $\mathrm{CO}_{2}$ medium. Palynov et al. (2007) on the basis of experimental data and thermodynamic calculations revealed the role of sulfides as a reducing agent for $\mathrm{CO}_{2}$-fluid and established the significance of pyrrhotite as a reducing agent regardless of its solid or melt state. According to them, the source through which diamond and/or graphite crystallizes is a $\mathrm{CO}_{2}$-dominated fluid/melt having dissolved carbon, silicates, oxides and 
sulfides. Phlogopite is abundant in glimmerite, and a very minor phase in spinellite. Therefore, it is possible that hydration reactions (removal of water from the system) leading to phlogopite crystallization is also a factor controlling graphite precipitation with the catalytic effect of sulfides playing only a minor role, at least in the case of glimmerite.

The solubility of $\mathrm{CO}_{2}$ in mantle melt/magma is solely dependant on pressure and oxygen fugacity (e.g., Lowenstern, 2001). Presence of graphite as inclusion and interstitial mineral together with incorporation of actinide components in zirconolite support low $f_{\mathrm{O}_{2}}$ environment. Low melting point of carbonates and the high mobility of carbonate melts suggest that carbon distribution in the mantle may be highly heterogeneous, including the possibility of massive carbon enrichments on a local scale, particularly in the shallow subcontinental mantle (Shcheka et al., 2006). The heat formed due to the collision of crustal blocks has aided in partial melting and generation of volatile-rich melts with $\mathrm{CO}_{2}$. The shear zone acted as a pathway for the upward movement of melts. The carbon isotope signature of graphite, hence, is suggestive of its derivation from a reduced juvenile mantle source linked to the genesis of volatile rich ultramafic rocks in ACSZ.

\section{ACKNOWLEDGMENTS}

V.J.R. greatly acknowledges Prof. M. Arima for his valuable encouragements and supports during his stay in Yokohama National University. We thank Prof. H. Wada for discussion and helps in $\mathrm{C}$-isotope analysis. Y. Kaneko is thanked for his analytical expertise during Laser Raman analysis. Constructive comments from Profs. J. Luque and N. Tsuchiya and editorial support from Prof. M. Obata are highly appreciated. V.J.R. acknowledges the grantin-aid (P 07331) from the Japan Society for the Promotion of Science (JSPS). MS-K acknowledges financial support from the Ministry of Education, Culture, Sports, Science and Technology (MEXT) in the form of grant-inaid for young scientists Nos. 18740319 and 20684022. This manuscript also contributes to IGCP project 509 (Palaeoproterozoic Supercontinents and Earth Evolution).

\section{REFERENCES}

Bartlett, J.M., Dougherty-Page, J.S., Harris, N.B.W., Hawkesworth, C.J. and Santosh, M. (1998) The application of single zircon evaporation and model $\mathrm{Nd}$ ages to the interpretation of polymetamorphic terrains: an example from the Proterozoic mobile belt of South India. Contributions to Mineralogy and Petrology, 131, 181-195.

Beyssac, O., Goffe, B., Chopin, C. and Rouzaud, J.N. (2002) Raman spectra of carbonaceous material from metasediments: a new geothermometer. Journal of Metamorphic Geology, 20, $859-871$

Binu-lal, S.S., Kehelpannala, K.V.W., Satish-Kumar, M. and Wada, H. (2003) Multistage graphite precipitation through protracted fluid flow in sheared metagranitoid, Digana, Sri Lanka: evidence from stable isotopes. Chemical Geology, 197, 253-270.

Bottinga, Y. (1969) Carbon isotope fractionation between graphite, diamond and carbon dioxide. Earth and Planetary Science Letters, 5, 301-307.

Cenki, B., Braun, I. and Bröcker, M. (2004) Evolution of the continental crust in the Kerala Khondalite Belt, southernmost India: evidence from $\mathrm{Nd}$ isotope mapping combined with $\mathrm{U}-\mathrm{Pb}$ and $\mathrm{Rb}-\mathrm{Sr}$ geochronology. Precambrian Research, 134, 275292.

Chacko, T., Mayeda, T.K., Clayton, R.N. and Goldsmith, J.R. (1991) Oxygen and carbon isotope fractionation between $\mathrm{CO} 2$ and calcite. Geochimica et Cosmochimica Acta, 45, 411-419.

Crespo, E., Luque, F.J., Rodas, M., Wada, H. and Gervilla, F. (2006) Graphite-sulfide deposits in Ronda and Beni Bousera peridotites (Spain and Morocco) and the origin of carbon in mantle-derived rocks. Gondwana Research, 9, 279-290.

Dienes, P. (1989) Stable isotope variations in carbonatite. In Carbonatites: genesis and evolution (Bell, K. Ed.). Unwin Hyman, London, 301-359.

Dienes, P. (2002) The carbon isotope geochemistry of mantle xenoliths. Earth-Science Reviews, 58, 247-278.

Dienes, P., Stachel, T. and Harris, J.W. (2009) Systematic regional variations in diamond carbon isotopic composition and inclusion chemistry beneath the Orapa kimberlite cluster, in Botswana. Lithos, in press.

Doroshkevich, A.G., Wall, A.F. and Ripp, A.G.S. (2007) Magmatic graphite in dolomite carbonatite at Pogranichnoe, North Transbaikalia, Russia. Contributions to Mineralogy and Petrology, 153, 339-353.

Drury, S.A. and Holt, R.W. (1980) The tectonic framework of the south Indian craton: a reconnaissance involving LANDSAT Imagery. Tectonophysics, 65, T1-T5.

Drury, S.A., Harris, N.B.W., Holt, B.W., Reeves-Smith, G.J. and Wightman, R.T. (1984) Precambrian tectonics of crustal evolution in South India. Journal of Geology, 92, 3-20.

Farquhar, J., Hauri, E. and Wang, J. (1999) New insights into carbon fluid chemistry and graphite precipitation: SIMS analysis of granulite facies graphite from Ponmudi, South India. Earth and Planetary Science Letters, 171, 607-621.

Geological Survey of India (1995) Geological map of Kerala, Tamil Nadu and Pondicherry on 1: 500000 scale. Geological Survey of India, Calcutta.

Ghosh, J.G., de Wit, M.J. and Zartman, R.E. (2004) Age and tectonic evolution of Neoproterozoic ductile shear zones in the southern Granulite Terrane of India, with implications for Gondwana studies. Tectonics, 23, TC3006.

Guru Rajesh, K. and Chetty, T.R.K. (2006) Structure and tectonics of the Achankovil Shear Zone, southern India. Gondwana Research, 10, 86-98.

Hoefs, J. (1980) Stable Isotope Geochemistry. pp. 288, Springer Verlag, New York.

Ishii, S., Tsunogae, T. and Santosh, M. (2006) Ultrahigh-temperature metamorphism in the Achankovil Zone: implications for the correlation of crustal blocks in southern India. Gondwana Research, 10, 99-114.

Javoy, M., Pineau, F. and Delorme, H. (1986) Carbon and nitrogen 
isotopes in the mantle. Chemical Geology, 57, 41-62.

Lamb, W. and Valley, J.W. (1985) Metamorphism of reduced granulites in low $\mathrm{CO}_{2}$ vapour free environments. Nature, 312 , 56-58.

Lowenstern, J.B. (2001) Carbon dioxide in magmas and implications for hydrothermal systems. Mineralium Deposita, 36, 490-502.

Luque, F.J., Ortega, L., Barrenechea, J., Millward, D., Beyssac, O. and Huizenga, J.M. (2009) Deposition of highly crystalline graphite from moderate temperature fluids. Geology, 37, 275-278.

Luque, F.J., Pasteris, J.D., Wopenka, B., Rodas, M. and Barrenechea, J.F. (1998) Natural fluid-deposited graphite: mineralogical characteristics and mechanisms of formation. American Journal of Science, 298, 471-498.

Luque, F.J., Rodas, M. and Galán, E. (1992) Graphite vein mineralization in the ultramafic rocks of southern Spain: mineralogy and genetic relationships. Mineralium Deposita, 27, 226233.

Mattey, D.P. (1987) Carbon isotopes in the mantle. Terra Cognita, 7, 31-37.

Nandakumar, V. and Harley, S.L. (2000) A reappraisal of the pressure temperature path of granulites from the Kerala Khondalite Belt, southern India. Journal of Geology, 108, 687-703.

Palyanov, Yu.N., Borzdov, Yu.M., Bataleva, Yu.V., Sokol, A.G., Palyanova, G.A. and Kupriyanov, I.N. (2007) Reducing role of sulfides and diamond formation in the Earth's mantle. Earth and Planetary Science Letters, 260, 242-256.

Pasteris, J.D. and Wopenka, B. (1991) Raman spectra of graphite as indicators of degree of metamorphism. The Canadian Mineralogist, 29, 1-9.

Pineau, F., Javoy, M. and Kornprobst, J. (1987) Primary igneous graphite in ultramafic xenoliths: II. Isotopic composition of the carbonaceous phases present in xenoliths and host lava at Tissemt (Algerian Sahara). Journal of Petrology, 28, 313322.

Polyakov, V.B. and Kharlashina, N.N. (1995) The use of heat capacity data to calculate carbon isotope fractionation between graphite, diamond, and carbon dioxide: a new approach. Geochimica et Cosmochimica Acta, 59, 2561-2572.

Radhika, U.P. and Santosh, M. (1996) Shear-zone hosted graphite in southern Kerala, India: implications for $\mathrm{CO}_{2}$ infiltration. Journal of Southeast Asian Earth Sciences, 14, 265-273.

Rajesh, H.M., Santosh, M. and Yoshida, M. (1996) The felsic magmatic province in East Gondwana: implications for PanAfrican tectonics. Journal of Southeast Asian Earth Sciences, 14, 275-292.

Rajesh, V.J. (2004) Graphite-dolomite-phlogopite bearing ultramafic rocks in Achankovil Shear Zone, South India: implications for highly potassic carbon-rich fluid influx along an intra-continental shear zone. pp. 154, Ph.D. thesis, Yokohama
National University, Japan.

Rajesh, V.J. and Arai, S. (2006) Baddeleyite-apatite-spinel-phlogopite (BASP) rock in Achankovil Shear Zone, South India, as a probable cumulate from melts of carbonatite affinity. Lithos, $90,1-18$.

Rajesh, V.J., Arima, M. and Santosh, M. (2004). Dunite, glimmerite and spinellite in Achankovil Shear Zone, South India: highly potassic $\mathrm{CO}_{2}$-rich melt influx along an intra-continental shear zone. Gondwana Research, 7, 961-974.

Rajesh, V.J., Yokoyama, K., Santosh, M., Arai, S., Oh, C.W. and Kim, S.W. (2006) Zirconolite and baddeleyite in an ultramafic suite from southern India: Early Ordovician carbonatitetype melts associated with extensional collapse of the Gondwana crust. Journal of Geology, 114, 171-188.

Santosh, M. (1987) Cordierite gneisses of southern Kerala, India: petrology, fluid inclusions and implications for crustal uplift history. Contributions to Mineralogy and Petrology, 96, 343356.

Santosh, M., Tanaka, K., Yokoyama, Y. and Collins, A.S. (2005) Late Neoproterozoic- Cambrian felsic magmatism along transcrustal shear zones in southern India: $\mathrm{U}-\mathrm{Pb}$ electron microprobe ages and implications for the amalgamation of the Gondwana supercontinent. Gondwana Research, 8, 31-42.

Satish-Kumar, M. (2005) Graphite-bearing $\mathrm{CO}_{2}$-fluid inclusions in granulites: Insights on graphite precipitation and carbon isotope evolution. Geochimica et Cosmochimica Acta, 69, 3841-3856.

Satish-Kumar, M., Wada, H. and Santosh, M. (2002) Constraints on the application of carbon isotope thermometry in high- to ultra-high temperature metamorphic terranes. Journal of Metamorphic Geology, 20, 335-350.

Shcheka, S.S., Wiedenbeck, M., Frost, D.J. and Keppler, H. (2006) Carbon solubility in mantle minerals. Earth and Planetary Science Letters, 245, 730-742.

Shimpo, M., Tsunogae, T. and Santosh, M., (2006). First report of garnet-corundum rocks from Southern India: implications for prograde high-pressure (eclogite-facies?) metamorphism. Earth and Planetary Science Letters, 242, 111-129.

Weis, P.L., Friedman, I. and Gleason, J.P. (1981) The origin of epigenetic graphite: evidence from isotopes. Geochimica et Cosmochimica Acta, 45, 2325-2332.

Windley, B.F., Razafiniparany, A., Razakamana, T. and Ackermand, D. (1994) Tectonic framework of the Precambrian of Madagascar and its Gondwana connections: a review and reappraisal. Geologische Rundschau, 83, 642-659.

Manuscript received June 22, 2009

Manuscript accepted November 2, 2009

Published online November 26, 2009

Manuscript handled by Masaaki Obata 